\title{
The Effect of Extensive Reading on the Vocabulary Mastery at the Seventh Grade Students of Junior High School
}

\author{
Halimatus Sa'diyah \\ MTs Hasyim Asy’ari Sukodono, Email: halimatussadiyah1410@gmail.com
}

\begin{abstract}
The objective of this research was to know there was influence effect between extensive reading on the vocabulary mastery at the seventh-grade students of junior high school of MTs Hasyim Asy'ari Sukodono. The subject of this research is 7.1 and 7.2 students from the seventh grade. The method used in this research quasi-experimental. In collecting the data, the researcher used four steps that was analyzed. The first step was pre-test to the both experimental and control group. The second step was giving treatment in terms of extensive reading process to the experiment group. The next step was giving post-test to the both control and experimental group. Then, the fourth step was to know whether the opinion of the students about extensive reading for the vocabulary mastery using questionnaire. In analyzing the data, the researcher analyzed them by using statistical analysis in SPSS 16.0 by comparing the result of pre-test and post-test from the students. The result of data from this research was counted to know whether the experiment was successes or not. The result of this research shows that there is an effect between extensive reading on the vocabulary mastery. Based on the study presented that sig. 2 tailed (p) was 0.003 though alpha $(\alpha)$ was 0.05. It means $p<\alpha$. It can be concluded that the HO (Null Hypothesis) was rejected and Ha (Alternative Hypothesis) was accepted. It proved that extensive reading is effective in improving students' vocabulary mastery.
\end{abstract}

Keywords: extensive reading, vocabulary mastery

\section{INTRODUCTION}

As a language student, vocabulary takes important role in the part of language skills. Pazhakh and Soltani (2010) explained that one of the factors of effective communication is about how to use vocabulary accurately and appropriately. There are some reasons why some students have no more vocabularies. These reasons are explained further by Pazhakh and Soltani (2010). They said that most EFL students are learning passively about vocabularies because of several factors.

Dealing with the importance of reading, it can be cleared that teaching technique has important role to give a big impact of vocabulary mastery of the students. Extensive reading comes as better technique to vocabulary mastery for the student's language learning. Iqbal 
and Komal (2017) make intelligible that by using extensive reading, the students will be exposed to get many times of reading with pleasure. Iqbal and Komal (2017) further also spells out that through extensive reading the students may read whatever kinds of the topic based the grade reader.

In this extensive reading teaching technique, teachers will have to be as good as possible as a controller. The teacher has to allow the students take whatever books they like. Iqbal and Komal (2017) put into words that the freedom to choose their own book even low ability students will not feel embarrassment in choosing books and progressing along with the high achievers. On the other hand, Iqbal and Komal (2017) view that students will not be depressed or less motivated and the overall impact of extensive reading will be positive. Moreover, students become independent readers with more motivation and encouragement to read and understand.

Based on those facts, that was why in this study the researcher wanted to know more about the effect of extensive reading on the vocabulary mastery at the seventh-grade students of MTs Hasyim Asy'ari Sukodono.

\section{LITERATURE REVIEW}

This study based on some theories. the researcher provides some of explanation about what reading is. First, the explanation comes from Benettayeb (2010). He said that reading is a part our daily life like people has to understand all kinds of signs in the life, and people have to understand all the signs that we see. Benettayeb (2010) also explains further that reading as a skill is a complex process involving the interaction of various cognitive, metacognitive, linguistic and sociolinguistic elements. Benettayeb cited Dubin (1982:125) explains that reading is complex because it can be understood by multifaceted like from psychological, psychical and social elements. On the other hand, Haryono (2016) said that reading skill is integral part of our daily activity which is important for people's academic, personal and social lives. Faliyanti (2015) explained that reading comprehension is the level of passage or text 
understanding while reading. Based on the explanation above it can be stated that reading is an activity to get more information from written language.

There are several types of reading in the language teaching and learning. There are two types of reading. The first is intensive reading and the second is extensive reading. This type of reading has ever been stated by Brno (2014). He stated that reading has two types in English classroom called intensive and extensive reading. Based on the understanding of intensive reading, Brno (2014) explained that intensive reading is the way teacher provide some passages to the students. On the other hand, Scrivener (2005) explained that intensive reading is an activity which involves "reading texts closely and carefully with the intention of gaining understanding of as much detail as possible".

To get more understanding in the second language, vocabulary comes as the big important in the second language. The researcher provides some of the understanding of vocabulary. Ayuningtyas (2011) cited Hornby (2000:144) there are three explanations of vocabulary,They are (1) all the words that people use or know, (2) all words in particular language, (3) the words that people use when they are talking about a particular subject, and ( 4) a list of words with their meanings. Ayuningtyas (2011) concluded that vocabulary is a language consists of a number of words which is a meaningful.

\section{RESEARCH METHODOLOGY}

In this research, the writer used a quantitative design, which was conducted with experimental research design. There are some explanations from some experts in this study about experimental research. According to Latief (2017), experimental research is the measurement of effect one of manipulated and controlled (independent) variable to another (dependent) variable. Data collection was done through the following steps. In short, there were four steps to collect the data that were analyzed. The first step was pre-test. The researcher distributed the pre-test to the both experimental and control group to know the ability on both groups. The second step was giving treatment in terms of extensive reading process to the experiment group. The next step was giving post-test. Post-test distributed to the both control and experimental group. Then, the fourth step was whether to know the opinion of the students about extensive reading for the vocabulary mastery using questionnaire. After doing the posttest, the researcher distributed questionnaire in the last activity. 
The Effect of Extensive Reading on the Vocabulary Mastery at the Seventh Grade Students of Junior High School

\section{RESEARCH FINDINGS AND DISCUSSION}

\section{Findings}

findings show that extensive reading on the vocabulary mastery at the seventh-grade student of junior high school. The students' score in pre- test and post-test of experimental class, which was taught using extensive reading, was class 7.1. But the control group was class 7.2 that was taught using conventional reading.

The scores of pre-test and the post test can be seen in table 1 as follows:

Table 1. The Score of Pre -Test and Post Test of Experimental Class (7.1)

\begin{tabular}{|c|c|c|}
\hline Student & Pre-Test & Post-Test \\
\hline 1 & 45 & 60 \\
\hline 2 & 45 & 60 \\
\hline 3 & 45 & 70 \\
\hline 4 & 50 & 70 \\
\hline 5 & 40 & 55 \\
\hline 6 & 35 & 50 \\
\hline 7 & 60 & 75 \\
\hline 8 & 55 & 70 \\
\hline 9 & 60 & 80 \\
\hline 10 & 55 & 75 \\
\hline 11 & 45 & 65 \\
\hline 12 & 50 & 60 \\
\hline 13 & 60 & 70 \\
\hline 14 & 55 & 70 \\
\hline 15 & 55 & 80 \\
\hline 16 & 50 & 65 \\
\hline 17 & 45 & 60 \\
\hline 18 & 65 & 80 \\
\hline 19 & 40 & 65 \\
\hline 20 & 45 & 70 \\
\hline 21 & 50 & 70 \\
\hline 22 & 60 & 70 \\
\hline 23 & 50 & 75 \\
\hline 24 & 50 & 65 \\
\hline 25 & 40 & 60 \\
\hline 26 & 45 & 65 \\
\hline 27 & 65 & 80 \\
\hline 28 & 45 & 65 \\
\hline 29 & 55 & 70 \\
\hline 30 & 40 & 55 \\
\hline Total Score & 1510 & 2025 \\
\hline Mean Score & 50,33 & 67,50 \\
\hline
\end{tabular}


The Effect of Extensive Reading on the Vocabulary Mastery at the Seventh Grade Students of Junior High School

Result of Pre-test of Experimental Class (Class 7.1)

Table 2. Data Statistics of Pre-Test Result of Experimental Class

\begin{tabular}{|l|r|}
\hline \multicolumn{2}{|c|}{ Value } \\
\hline N Valid & 30 \\
Missing & 0 \\
Median & 50.33 \\
Mode & 45 \\
Std. Deviation & 8.66 \\
Variance & 75 \\
Range & 30 \\
\hline
\end{tabular}

Table 3. Data Statistics of Post -Test Result of Experimental Class

\begin{tabular}{|l|r|}
\hline \multicolumn{2}{|c|}{ Value } \\
\hline N Valid Missing & 30 \\
Median & 0 \\
Mode & 67,5 \\
Std. Deviation & 70 \\
Variance & 8.32 \\
Range & 69.24 \\
& 30 \\
\hline
\end{tabular}

Table 4. The Score of Pre-Test and Post Test of Controlled Class

\begin{tabular}{|c|c|c|}
\hline Student & Pre-Test & Post-Test \\
\hline 1 & 55 & 60 \\
\hline 2 & 45 & 60 \\
\hline 3 & 45 & 45 \\
\hline 4 & 35 & 50 \\
\hline 5 & 45 & 65 \\
\hline 6 & 60 & 50 \\
\hline 7 & 45 & 65 \\
\hline 8 & 55 & 60 \\
\hline 9 & 60 & 55 \\
\hline 10 & 40 & 65 \\
\hline 11 & 60 & 65 \\
\hline 12 & 60 & 60 \\
\hline 13 & 55 & 55 \\
\hline 14 & 40 & 60 \\
\hline 15 & 45 & 55 \\
\hline 16 & 45 & 65 \\
\hline 17 & 50 & 75 \\
\hline 18 & 70 & 75 \\
\hline 19 & 65 & 55 \\
\hline 20 & 40 & 6 \\
\hline
\end{tabular}




\begin{tabular}{|c|c|c|}
\hline 21 & 50 & 60 \\
\hline 22 & 55 & 65 \\
\hline 23 & 65 & 75 \\
\hline 24 & 55 & 70 \\
\hline 25 & 55 & 60 \\
\hline 26 & 45 & 55 \\
\hline 27 & 35 & 50 \\
\hline 28 & 60 & 70 \\
\hline 29 & 40 & 50 \\
\hline Total Score & 1475 & 1765 \\
\hline Mean Score & 50,86 & 60,86 \\
\hline
\end{tabular}

\section{Result of Pre-test of Controlled Class (7.2)}

The results from pre-test in class 7.2 as the controlled class of this study were showed in a table as follows:

Table 5. Data Statistics of Pre-test Result of Controlled class

\begin{tabular}{|l|r|}
\hline \multicolumn{2}{|c|}{ Value } \\
\hline N Valid & 29 \\
Missing & 0 \\
Median & 50.86 \\
Mode & 50 \\
Std. Deviation & 9.32 \\
Variance & 86.89 \\
Range & 30 \\
\hline
\end{tabular}

\section{Result of Post-test of Controlled Class}

The results from post-test in class 7.2 as the controlled class of this study were showed in a table as follows:

Table 6. Data Statistics of Post-test Result of Controlled class

\begin{tabular}{|l|r|}
\hline \multicolumn{2}{|c|}{ Value } \\
\hline N Valid Missing & 29 \\
Median & 0 \\
Mode & 60 \\
Std. Deviation & 60 \\
Variance & 7.81 \\
Range & 61 \\
& 30 \\
\hline
\end{tabular}

This is the extra calculation that used by the writer. These was used to measure what level of the effectiveness from the treatment of the study. 


$$
\mathrm{d}=\underline{\text { mean of experiment group }- \text { mean of control group }}
$$

pooled standard deviation

Mean of experiment group $=67.50$

Mean of controlled group $=60.86$

Mean of experimental group - mean for controlled group $=6.62$

Standard deviation for group $1=8.32$

Standard deviation for group $2=7.81$

Pooled standard deviation (standard deviation for group $1+$ standard deviation for group 2 ) $=$ $8.32+7.81=16.13$

$$
\begin{aligned}
& d=\underline{\text { mean of experimental group }- \text { mean of control group }} \\
& \text { pooled standard deviation } \\
& d=\underline{67,50-60.86}
\end{aligned}
$$

$$
\mathrm{d}=\underline{6.62}
$$

$$
\mathrm{d}=0.41
$$

The result of formulation will be interpreted based on the following criteria:

$0.00-0.20$ : weak effect

$0.21-0.50$ : modest effect

0.51 - 1.00: moderate effect

\section{$>$ 1.00: strong effect}

The result in this research was 0.41 . It shows that using extensive reading had significant effect in improving students' vocabulary mastery.

\section{Discussion}

According to the result of the data analysis, it was discovered that there was a significant difference between students' vocabulary mastery in the experimental class after giving treatment of extensive reading and the controlled class, which was not given treatment of extensive reading. The pre-test mean score for students in experimental class was 50,33, while the post-test mean score for students in experimental class was 67,50 so that the score increased in experimental class is 17.17. Meanwhile, the post-test mean score in controlled class was 60.86 , so the score increased in control class was 6.62 . 
Furthermore, in calculating t-test, if $\mathrm{p}<\alpha$, it meant that Ho was rejected, and Ha was accepted. But, if $p>\alpha$, it meant that Ho was accepted and Ha was rejected. The result of this research presented that $\mathrm{p}$ was 0.003 and $\alpha$ was $0.05(\mathrm{p}<\alpha)$. In other words, it specified that Ho was rejected and Ha was accepted. In fact, there was positive effect of using extensive reading on students' vocabulary mastery. In fact, the calculation of Cohen's d effect size showed 0.41, which meant that extensive reading had importance effect.

Through this research, the researcher believed that extensive reading could improve students' vocabulary mastery. Students who had experienced in extensive reading knew and mastered more English words, had their motivation and interest increased to read, and also could use the words in their daily activities. The result is extensive reading can increase the students' vocabulary mastery also in line with Hayashi's (1999) that his research is about one hundred Japanese university students' learners of English. Hayashi records significant correlation between the numbers of pages read, improved test scores, and improved vocabulary. Then the result based on the study is getting better score in quality of reading comprehension and vocabulary mastery.

This is a part to what students in experimental class had been practiced through the treatment. In fact, the results of this study also maintained the idea that extensive reading could give a positive effect on students' vocabulary mastery. The earlier research strengthens and support this study result that extensive reading had effect in improving students' vocabulary mastery. In other words, it was discovered that extensive reading was effective to improve the students' vocabulary mastery, especially for students at the seventh grade of MTs Hasyim Asy'ari Sukodono.

\section{CONCLUSIONS AND SUGGESTION}

\section{Conclusion}

Based on the study presented that sig. 2 tailed (p) was 0.003 though alpha $(\alpha)$ was 0.05 . It means $\mathrm{p}<\alpha$. It can be concluded that the HO (Null Hypothesis) was rejected and $\mathrm{Ha}$ (Alternative Hypothesis) was accepted. It proved that extensive reading is effective in improving students' vocabulary mastery of descriptive text. In addition, there is an effect between extensive reading and vocabulary mastery of descriptive text to the students. It means that the study of the effect of extensive reading on students' vocabulary mastery had important influence for the seventh grade of MTs Hasyim Asy'ari Sukodono. 


\section{Suggestion}

Based on the result of the study, the researcher wants to give some suggestions to:

1. The teacher: it is hoped that the teacher must use more imaginative and numerous media and materials in teaching vocabulary in class. One of materials that can be used is extensive reading since using extensive reading can attract the students' interest. Using extensive reading students will not only read the text but also know the authentic of the text.

2. The reader: it is hoped that the reader know that extensive reading is significant. It can easily comprehend the materials and the aim of the text.

3. For other researcher: It is only one of study that proves that extensive reading can be a useful media in increasing vocabulary mastery. In addition, the writer hopes that this study can be added and completed from different perspective, ideas and views in order to give more contribution in different perspective.

4. The title of this study is the effect of extensive reading on students' vocabulary mastery, but inappropriately types of reading used in this study, because of some reasons, is descriptive text. The additional research maybe can hold the research by other diverse types of text.

\section{REFERENCES}

Ayuningtyas, Dian. (2011) Improving Students' Vocabulary Mastery through Extensive Reading Activities at Grade Xi IPA 2 of SMAN 1 Pleret Bantul in the Academic Year of 2011/2012. Thesis Universitas Negeri Yogyakarta, Fakultas Humaniora.

Aini, Anggarina Nurul. (2017). An Experimental Study of Picture Series in Teaching Reading of Narrative Text at Eight Grade Students of SMP Ta'mirul Islam Surakarta in Academic Year 2016/2017. Thesis IAIN Surakarta

Brno. (2015). Extensive Reading in a Secondary School EFL Classroom. Masaryk University Press

Benettayeb, Assia. (2010) Extensive Reading and Vocabulary Teaching. Revue Académique des Études Sociales et Humaines. 1 (3)

Corson, D.J. (1997). The Learning and Use of Academic English Words. Pergamon Press: Oxford.

Calfoglou, C., \& Sifakis, N. (2004). Learning and teaching in an EFL context. Hellenic Open University. 
The Effect of Extensive Reading on the Vocabulary Mastery at the Seventh Grade Students of Junior High School

Day, R. \& Bamford, J. (1998). Extensive Reading in a Second Language Classroom. Cambridge: Cambridge University press.

Day. R. R \& Bamford, J. (2002). Top Ten Principles for Teaching Extensive Reading. Reading for Foreign Language. Cambridge Univeristy Press

Dubin.F. (1982). What every teacher should know about reading. Washington, D.C. USA

Grellet, F. (1981). Developing Reading Skills. Cambridge: Cambridge University Press.

Haryono. (2016) the Effects of Multimedia Learning and Vocabulary Mastery on Students' Japanese Reading Skills. Lingua Cultura. 10 (1)

Hedge, T. (2000). Teaching and Learning in the Language Classroom. Oxford: OUP

Iqbal, Syeda A \& Komal, Syeda A. (2017) Analyzing the Effectiveness of Vocabulary Knowledge Scale on Learning and Enhancing Vocabulary through Extensive Reading. Canadian Center of Science and Education. 10 (9)

Kerlinger, F. N. 1965. Foundation of Behavioral Research. New York: Hott Rinehart, and Winston, Inc.

Latief, Mohammad Adnan. (2017). Research Methods on Language Learning an Introduction. UM Press. Malang

Mikeladze, T. (2014). Implementing Extensive Reading in Georgian Universities. Tbilisi: Universal.

Mistar, Junaidi. (2013) Statistic for ELT Studies. Malang: University of Islam Malang

Pazhakh, Abdolreza., \& Soltani, Rahmatollah. (2010) The Effect of Extensive Reading on Vocabulary Development in EFL Learners in Dehdasht Language Institute. Practice and Theory in Systems of Education. 5 (4).

Richard, J.C. and W.A. Renandya. (2002). Methodology in Language Teaching. USA: Cambridge University Press.

Yang, Lijun. (2014) The Influence of Extensive Reading upon Vocabulary Acquisition. International Conference on Education, Language, Art and Intercultural Communication. 6 (3)

Wardani, Sri. (2014) Using Speed Reading and Extensive Reading Activities to Improve Students' Reading Fluency. Jurnal Pendidikan Humaniora. 2 (3) 